Geron, a biotechnology company in Menlo Park, California.

An early draft of Specter's bill that was circulating last week declares that "the Secretary [of Health and Human Services] may conduct, support or fund research on, or utilizing, human embryonic stem cells". It also says that federal funding could support the derivation of embryonic stem cells from leftover embryos resulting from in vitro fertilization, providing consent was given by the couple. But it was not clear that this provision would remain in the bill.

Specter indicated at a Senate hearing last week that he intended to try to lift the human embryo research ban as it applies to stem-cell research "at a very early stage" because of the potential for it to deal with serious diseases.

At the hearing, witnesses who implored Specter to exempt stem-cell research from the federal ban included a young man diagnosed with Parkinson's disease at the age of 27 and Doug Melton, chairman of the department of molecular and cellular biology at Harvard University, who has a sevenyear-old son with juvenile diabetes. Both diseases are among those for which stem-cell research is thought to hold most promise.

The biomedical community applauded the DHHS decision. "We are delighted," says William Brinkley, president of the Federation of American Societies for Experimental Biology. "This makes it possible for many more investigators in this country to have access to this technology." Ron Eastman, chief executive officer of Geron, calls it "good news for science and medicine".

But Richard Doerflinger, a spokesman for the National Conference of Catholic Bishops, protested that the decision means that the government will be providing incentives for embryo destruction. "The reward for destroying them is an NIH grant to work on the stem cells thus produced," he said. "It doesn't matter what you did to obtain the stem cells as long as whatever destruction is needed was done without federal funds."

Doerflinger noted that the law governing the use of fetal tissue in federally funded research prohibits carrying out abortions in order to get the tissue. A woman must have chosen an abortion for unrelated reasons,

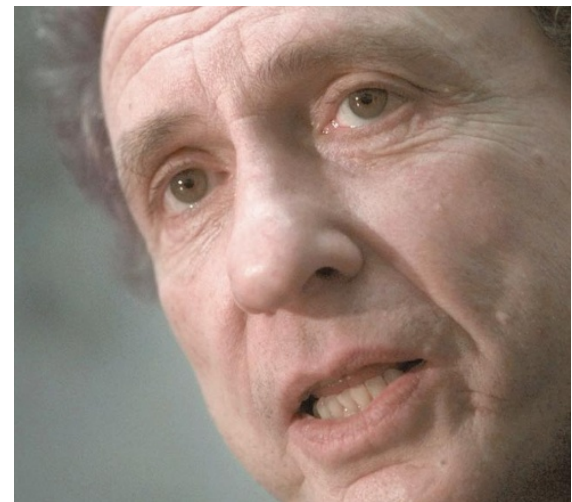

Specter: bill would allow funding for research on human embryonic stem cells.

and have no contact with the researcher. $\mathrm{He}$ says that destroying an embryo to obtain stem cells is morally equivalent to an abortion, and the new policy therefore contravenes the spirit of the existing law on the use of fetal tissue.

Conservative Republicans in Congress could challenge the DHHS decision by broadening the existing ban to explicitly include stem-cell research. MeredithWadman

\title{
Space station faces research cuts to cover risk of Russian default
}

[WASHINGTON] Space-station managers at the US space agency NASA are braced for a 30 per cent reduction in funds next year for research on the station. The lower-thanexpected allocation is to enable the agency to guard against a possible Russian default on delivering key elements of the station.

Although NASA's budget for the fiscal year 2000 will not be finalized until 1 February, the agency has been told by the White House Office of Management and Budget (OMB) to expect less than half the money it requested to cover such a situation.

OMB's refusal of the full request for contingency planning would result in a "considerable reduction in funding to the [space station] research programmes," says Michael Suffredini, manager of the spacestation payloads office at NASA's Johnson Space Center in Houston.

A memorandum sent by Suffredini to agency research managers on 8 January was leaked last week to NASA Watch, an independent website that tracks space policy issues. As a result of OMB's constraints, the space-station programme faces a $\mathbf{2 0 0}$ million shortfall over the next five years, plus an additional burden of $\$ 70$ million to pay for the development of new technology.

The easiest place to find the money without jeopardizing the space station's tight construction schedule is the research 'utilization' budget, which pays for NASAfunded scientists to develop hardware and experiments for the station. Agency science managers have therefore been asked to draw up plans to scale down their research programmes.

Top priority will be given to maintaining the launch schedule for large 'facility class' instruments, which will be used by many different researchers on the station. Priority will also be given to building hardware for individual experiments that have already passed key design reviews.

The cuts are targeted for the period when the station is being built, with research funding expected to rise again in 2003. NASA officials have promised that past reductions to the research budget would be restored by the time the orbiting laboratory is fully operational in 2004.

Suffredini's memo calls for the number of principal investigators preparing flight experiments to be held "at current levels". NASA had hoped to enlarge the pool of scientists, but the number is now anticipated

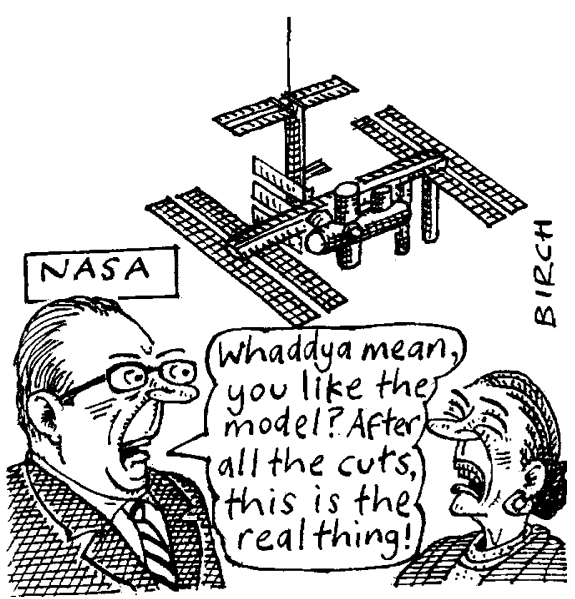

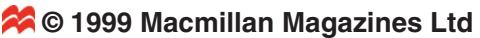

to fall by 30 per cent. Contractors are also likely to be laid off "in selected areas".

The number of scientists involved has been a "highly visible metric with Congress and the research community", wrote Suffredini. With the proposed cuts, "NASA's commitment to research on [the station] appears questionable".

The idea of raiding the station's research budget, even temporarily, to counter problems caused by the partnership with Russia is sure to raise hackles in Congress. Members of the House Science Committee, which oversees NASA's budget, have repeatedly warned the agency not to shortchange science, which has been a leading justification for the project.

Congressional appropriators last year ordered responsibility for the station research budget to be shifted from the human spaceflight office - which operates the space shuttle and is building the station - to the agency's Office of Life and Microgravity Sciences and Applications. But the change has yet to take place.

The reaction on Capitol Hill to a 30 per cent cut, says one congressional source, is likely to be "universally negative". Congress may add more money when it takes up NASA's budget request in the coming year.

Meanwhile, scientists working in the fields of microgravity and life sciences say they are only too accustomed to delays and dwindling budgets for space-station research. When told of the latest funding threat, one NASA-funded scientist quipped: "Ho hum, what else is new?" Tony Reichhardt 